\title{
FATIGUE LIFE ANALYSIS OF RAMP DOOR FERRY RO-RO GT 1500 USING FINITE ELEMENT METHOD
}

\author{
Alamsyah $^{1 *}$, A. B. Mapangandro ${ }^{1}$, Amalia Ika W. ${ }^{1}$, M U Pawara ${ }^{1}$ \\ ${ }^{1}$ Naval Architecture Program, Kalimantan Institute of Technology \\ E-mail: alamsyah@lecturer.itk.ac.id*
}

\begin{abstract}
Ro - Ro Ferry is equipped with a connecting door between the port and the ship. The ramp door experiences load during loading and discharging of the rolling cargo. This repetitive load may cause fatigue failure. The structure of the ramp door should withstand this load. Therefore, The ramp door should be properly designed to ensure the structural integrity of the ramp door. The purpose of this research is to analyze the maximum stress and the Fatigue life of the bow ramp door. The method used is the finite element method. The given loads are several types of vehicles that are commonly transported by the ship. The given load case is the point load working at the girder plate and between the girder plate. Based on the simulation results with the given point load, the maximum stress is identified located between the girder for the large truck case with $397.02 \mathrm{MPa}$, while the minimum stress located at the girder for sedan car with $43.93 \mathrm{MPa}$. As for the fatigue life of the bow ramp door construction. it is $1.17 \sim 398.64$ years, and the load cycle is $5.35 \times 10^{4} \sim 9.05 \times 10^{6}$ cycle.
\end{abstract}

Keywords : Bow Ramp Door; Stress; Fatigue Life; Finite Element; Ferry

\section{INTRODUCTION}

In Indonesia, Ro - Ro ship is used for crossings between islands, for example, Java and Sumatra, Java and Madura, and between Java and Bali. The Ro - Ro concept would not have been possible without the availability of special equipment such as ramps and elevators that would allow loading and unloading from ships. The ramp is used as the entrance to the ship and the access from the deck inside the ship. Internal ramps can be fixed or hinged.

There are several types of ramp doors used on the Ro-Ro ship, for example [1]:

1. Quarter Ramp Door

2. Side Ramp Door

3. Slewing Ramp Door

4. Stern Ramp Door

5. Foldable Stern Ramp Door

There are several rules regarding ramp door construction that need to be considered according to BKI rules, for example the allowable stress and materials used in the manufacture of the ramp door. In this case the allowable stress used is in accordance with the provisions of BKI Vol II Sec 6, H [2].
In the ramp door design, it should be ensured that the structure does not exceed the allowable stress design, the structure has sufficient elastic stiffness to avoid excessive elastic deformation [3]. The stress that occurs in the ramp door construction is normal stress which can also produce tensile stress, compressive stress, and shearing stress.

The method used in the present study is the Finite Element Method (FEM), this method has been applied in various ship structure problems from the simple case to the most complex ones. FEM is used to determine the fatigue life of the shaft propeller [4][5]. Alamsyah et al., analyzed the strength of pontoon lift and its fatigue life using FEM [6]. Munandar et al., investigated the transverse strength of the container ship's deck due to all container loads using FEM [7]. The finite element analysis application works with the finite element method system where the solution to the object is done by discretizing it by dividing or splitting the object of one unit into a finite number of elements, namely into smaller parts connected by nodes. This process is meshing [8]. In this research, the Quarter Ramp door is used [9]. The bow ramp door construction is simulated to receive dynamic loads in the form of various 
kinds of vehicles that are predominantly transported by crossing ships. Construction will be assessed from a safety factor that is identical to the ratio between the ultimate stress and the allowable stress of a material. It is also stated that the safety factor indicates the ability of an engineering material to accept external loads in the form of tensile loads and compressive loads.

This research will also estimate the fatigue life of the bow ramp door construction. Fatigue Life is computed to predict the lifetime of the construction due to dynamic loads (repeated or changing loading). It is estimated that $50 \%-90 \%$ of mechanical failure is due to fatigue. S-N Curve is the first approach for understanding the metal fatigue phenomenon. However, The S-N Curve has shortages, it cannot be used in the plastic area, and fatigue life relatively short. The fatigue life is determined based on the procedure in the rules refers to S-N Curve [10].

\section{METHODS}

In the present study, the finite element method is used, and the analysis is carried out by finite element-based applications. The type of data used in this study is primary data needed for the modelling process of the bow ramp door. The main size data for the bow ramp door is shown in Table 1.

In addition to the main data of the bow ramp door, detailed 2D construction of the ramp door is also used as shown in Figure. 1

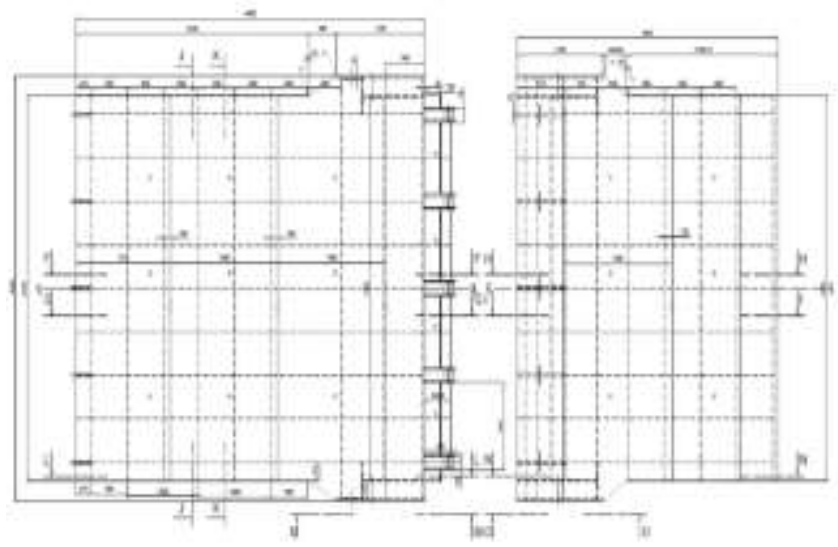

Figure 1.

Detail Construction of bow ramp door (stiffener, girder, deck plate etc.)
Table 1.

Dimension bow ramp door

\begin{tabular}{lll}
\hline Particular & value & units \\
\hline L (Length) & 8500 & $\mathrm{~mm}$ \\
B (Breadth) & 4400 & $\mathrm{~mm}$ \\
H (Height) & 324 & $\mathrm{~mm}$ \\
Plate Thickness & 12 & $\mathrm{~mm}$ \\
\hline
\end{tabular}

Figure 1 shows the details of the bow ramp door construction of the ship which is the object of research where the construction will be modeled in 3D on a finite element based application. This method can be used to analyze the strength of construction components on ships from the most complex to the simplest, such as the brackets [11].

In this modeling using the $\mathrm{x}, \mathrm{y}$ and $\mathrm{z}$ axes or commonly referred to as $3 \mathrm{D}$ model. Where in this case, the $x$-axis represents the width of the model design, the $y$-axis represents the length of the model design, and the z-axis represents the thickness or height of the model design.

The next step is to calculate the load on the bow ramp door. The load used is the load point at the girder and than the load point between the girders. The load used is shown in Table 2.

Table 2. [12]

Load Vehicle type of bow ramp door

\begin{tabular}{lcc}
\hline $\begin{array}{c}\text { Vehicle } \\
\text { type }\end{array}$ & value & units \\
\hline MPV & 1948.85 & $\mathrm{~kg}$ \\
SUV & 2268.18 & $\mathrm{~kg}$ \\
Sedan car & 1693.67 & $\mathrm{~kg}$ \\
Commercial & 2057.67 & $\mathrm{~kg}$ \\
Little truck & 7341.82 & $\mathrm{~kg}$ \\
Big truck & 27239.2 & $\mathrm{~kg}$ \\
bus & 16036.36 & $\mathrm{~kg}$ \\
\hline
\end{tabular}

The next step is to calculate the stress that occurs in the construction of the bow ramp door. A stress at a point, can be found mathematically using Equation. (1) :

$$
\sigma=\frac{P}{A}
$$

Where $\mathrm{P}$ is a force acting perpendicular to the cross-section, while $A$ is the area concerned. In addition, normal stress can produce tensile 
stress, compressive stress and shearing stress [13].

Exactly, there are 2 stress values that occur in the bow ramp door construction, namely the stress that occurs on the load that is placed right on the girder of the bow ramp door and the load that is placed between the girders of the bow ramp door. Both load models apply to all types of vehicles. An illustration of placing a load is shown in Figure 2.
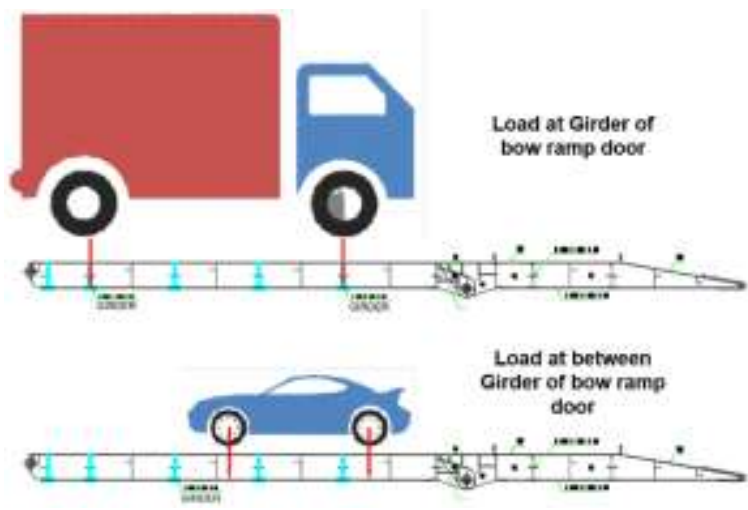

Figure 2.

Loadcase of bow ramp door

The next step is to determine the value of the construction safety factor by comparing the results of maximum stress that occurs in the construction with the yield stress of the materials used in the construction. To calculate the safety factor, Equation (2) is used.

$$
S F=\frac{\sigma_{\text {ultimate }}}{\sigma_{\text {allowable }}}
$$

Where $\sigma_{\text {ultimate }}$ is the material of ultimate stress, $\sigma_{\text {allowable }}$ is the maximum stress allowable in the construction, and SF is the safety factor $(S F>1)$. The calculation of the ultimate stress on the bow ramp door uses the provisions [2] shown in Equation (3), (4), and (5) as follows:

\section{Bending stress ;}

$$
\sigma=\frac{120}{k}
$$

shear stress ;

$$
\tau=\frac{80}{k}
$$

Equivalent stress ;

$$
\sigma v=\sqrt{\sigma^{2}+3 \tau^{2}}=\frac{150}{k}
$$

where ;

$$
k=\frac{235}{R_{e H}}
$$

Where $\mathrm{k}$ is the material factor. $\mathrm{ReH}$ is the minimum upper yield point of material (Yield Stress).

In the last step, determining fatigue life according to DNV rules. To determine fatigue life, it is necessary to know the value of fatigue damage first using a simplified fatigue analysis taken from DNVGLRP-0005: 2014-06 [10]. The value of fatigue damage can be determined using Equation (7), (8), (9), (10), and (11):

$$
D=\frac{v_{0} T_{d}}{\bar{a}} q^{m} r\left(1+\frac{m}{n}\right) \leq \eta
$$

$$
v_{0}=\frac{1}{4 . \log _{10}(L)}
$$

$$
\begin{aligned}
& q=\frac{\Delta \sigma_{0}}{\left(\operatorname{In} n_{0}\right)^{1 / h}} \\
& h_{0}=2.21-0.54 \log _{10}(L)
\end{aligned}
$$

$$
\mathrm{h}=h_{0}+\frac{h_{\mathrm{a}} \times z}{T_{\mathrm{act}}}-0.005\left(T_{\mathrm{act}}-\mathrm{z}\right)
$$

$D$ is accumulated fatigue damage, $v_{0}$ is average zero up-crossing frequency, $q$ is weibull stress range scale distribution parameter, $h$ is weibull stress range shape distribution parameter, $\mathrm{Td}$ is design service life of ship, $r(1+m / h)$ is gamma function, $a^{-}$is intercept of the design S- $N$ curve with the $\log N$ axis, and $\Delta \sigma_{0}$ is the largest stress range out of $n_{0}$ cycles.

After the fatigue damage is known then Equation (12) is used to determine the fatigue life of the structure. 


$$
\text { Fatigue Life }=\frac{\text { Design Life }}{D} \times \text { years }
$$

Fatigue life is the fatigue life of construction, design life is used 20 years according to DNV rules, $D$ is fatigue damage, and years is used for 1 year.

\section{RESULTS AND DISCUSSION}

\section{The Material Optional}

The material used in the construction of the bow ramp door is $\mathrm{BKI} \mathrm{KI-A36}$ material that is in accordance with the provisions of BKI [2], the material is inputted in finite element-based software. Material specifications are shown in Table 3.

Table 3.

The material Spesific BKI KI-A36 [2]

\begin{tabular}{lcc}
\hline Properties & value & units \\
\hline Modulus Y. & 200 & $\mathrm{GPa}$ \\
Tensile Stress & 400 & $\mathrm{MPa}$ \\
Yield & 235 & $\mathrm{MPa}$ \\
Sh Modulus & 79.3 & $\mathrm{GPa}$ \\
Poisson R. & 0.3 & - \\
Density & 7.8 & tons $/ \mathrm{m}^{3}$ \\
\hline
\end{tabular}

\section{Modelling 3D of Bow Ramp Door}

Bow ramp door modeling is done based on data from Table 1 and Figure. 1. Modeling is done in 3D or commonly known as 3D modeling. The bow ramp door modeling of the finite element analysis software is shown in Figure 3.

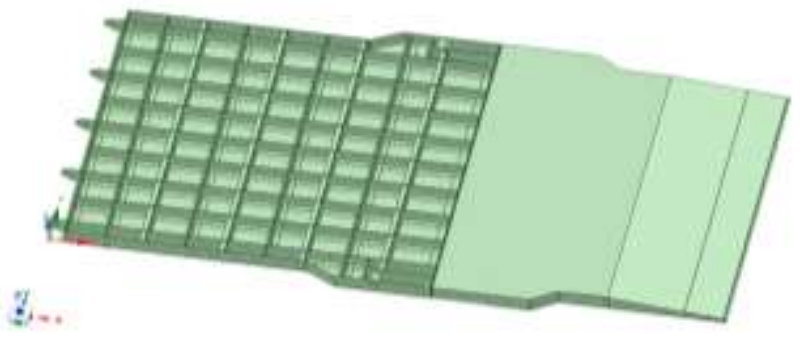

Figure 3.

3D modelling of bow ramp door

\section{Meshing Modelling of Bow Ramp Door}

Meshing is dividing the model into small uniform elements in order to make the analysis more detail. Factors that must be considered are the mesh size, mesh type, and size function. The meshed model is shown in Figure 4.

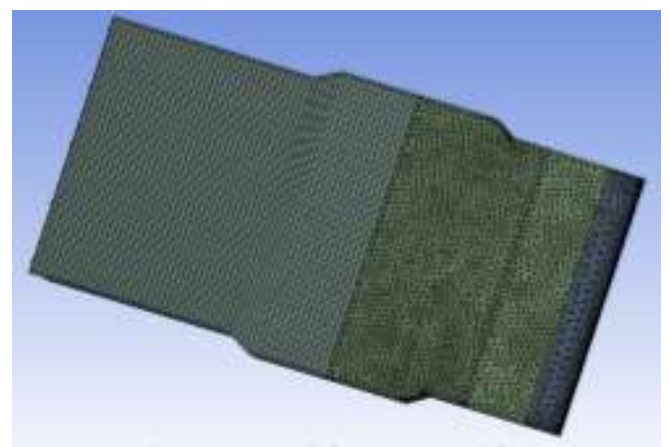

Figure 4.

Meshing 3D modelling of bow ramp door

\section{Input Displacement (Fixed Support \& Roll Support)}

In this research, the pedestal used is in accordance with the actual conditions. pinch pedestal and a roll pedestal are used. The supports on the bow ramp door model are shown in Figure 5.

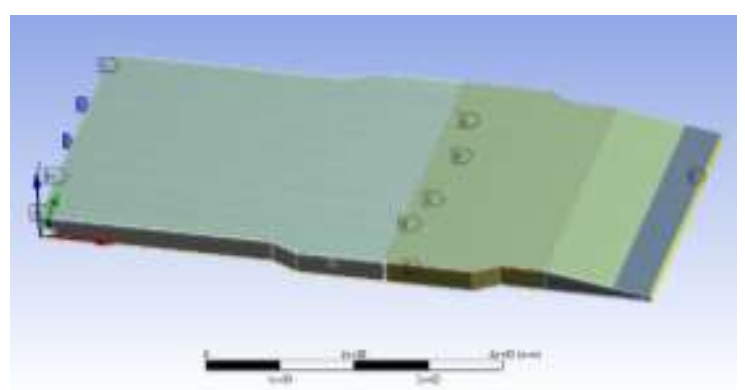

Figure 5.

Input fixed support \& roll support

Figure. 5 indicates that each letter in the image indicates its location and role. The letters $A B, C, D, E$, and $F$ indicate the location of the roll support that is input to the 3D model. Meanwhile, the letters $\mathrm{G}, \mathrm{H}, \mathrm{I}$, and $\mathrm{J}$ denote the fixed support.

\section{Input Loadcase (load at girder \& load between Girder)}

A point load is given based on the load concept shown in Figure 2 and the load values in Table 2. The point load uses the average dimensions of each type of vehicle. To simplify the analysis, it is assumed that, in the load case, 
the load is equally distributed to all wheels of the vehicle point of load. The load input is shown in Figure 6 \& 7 .

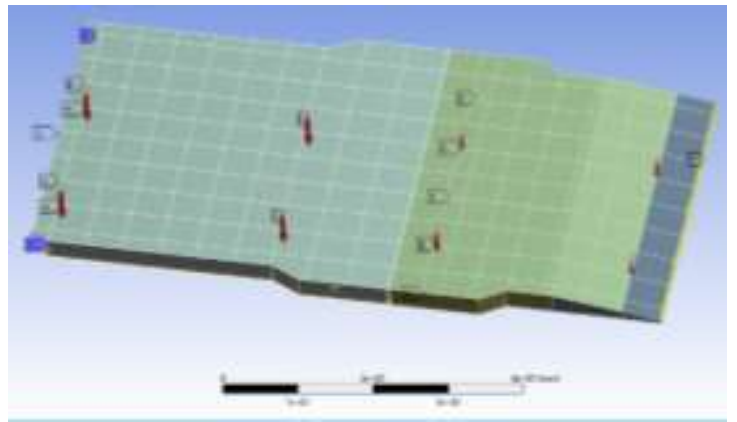

Figure 6.

Input load at girder bow ramp door

Figure 6 \& 7 shows that the bow ramp door is given 2 loads of 4 -wheeled vehicles so that the load given is 8 concentrated loads which are symbolized by a red arrow pointing downward.

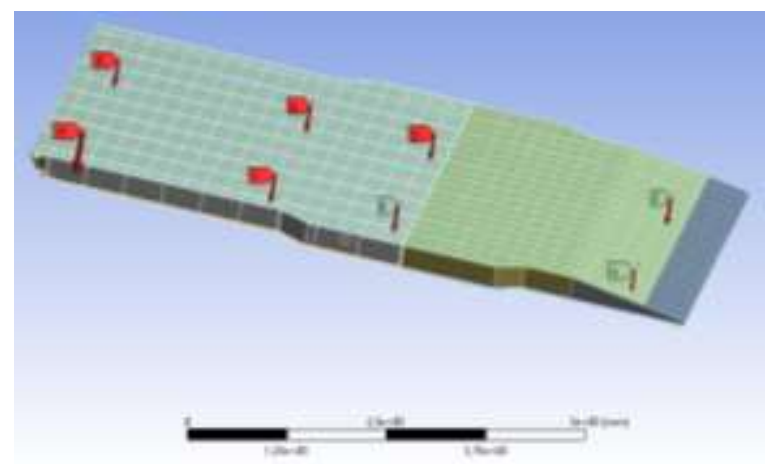

Figure 7.

Input load at girder bow ramp door

\section{Stress Analysis}

The stress analysis at point loads is carried out on two loadcases, namely the point load where the load is supported and the point load where the load is not supported. Stress analysis is carried out on all types of vehicles that are planned to be load on the bow ramp door. The results of the stress analysis are shown in Figure $8 \& 9$.

Figure 8 \& 9 shows the value of stress detected in the bow ramp door construction after being given one of the planned types of vehicles. The recapitulation of the detected stress values in the bow ramp door construction with 2 types of load cases and the planned type of vehicle is shown in Table 4.

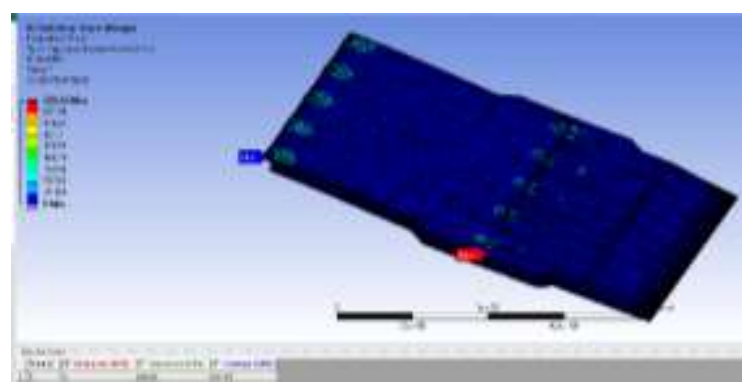

Figure 8.

Stress at loadcase given at girder bow ramp door

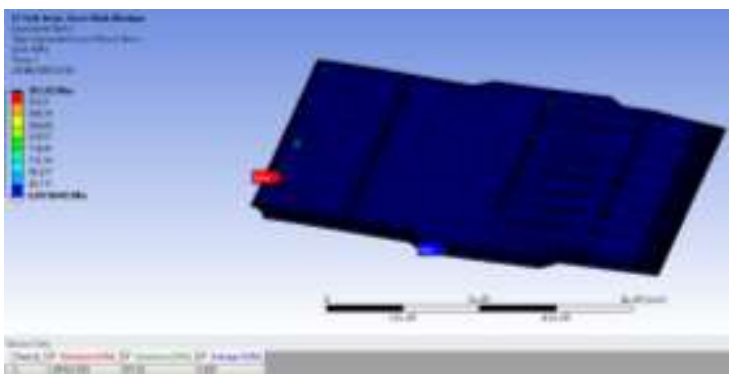

Figure 9.

Stress at loadcase given between girder bow ramp door.

Table 4.

The maximum stress at bow ramp door Construction

\begin{tabular}{lcc}
\hline $\begin{array}{c}\text { Vehicle } \\
\text { type }\end{array}$ & Load positioning & $\begin{array}{c}\text { Max. } \\
\text { Stress } \\
\text { (Mpa) }\end{array}$ \\
\hline MPV & at girder & 52.23 \\
SUV & at girder & 58.84 \\
Sedan car & at girder & 43.93 \\
Commercial & at girder & 53.38 \\
Little truck & at girder & 53.28 \\
Big truck & at girder & 226.65 \\
Bus & at girder & 110.74 \\
MPV & between. Girder & 106.07 \\
SUV & between. Girder & 120.13 \\
Sedan car & between. Girder & 89.70 \\
Commercial & between. Girder & 111.99 \\
Little truck & between. Girder & 101.79 \\
Big truck & between. Girder & 397.02 \\
Bus & between. Girder & 230.83 \\
\hline
\end{tabular}

Table 4 shows that the highest detected stress for each type of vehicle load using 2 load schemes is shown in the type of big truck with the 
type of load placement between the girders, equal $397 \mathrm{MPa}$. While the lowest was detected in the type of sedan car with the type of load laying on the girder, equal 43.94 Mpa.

\section{Safety Factor}

The safety factor for the bow ramp door construction is determined by Equation. 2, so that the safety factor value is shown in Table 5.

Table 5.

Safety Factor Construction of bow ramp door

\begin{tabular}{lccl}
\hline $\begin{array}{c}\text { Vehicle } \\
\text { type }\end{array}$ & $\begin{array}{c}\text { Yield } \\
\text { Stress } \\
\text { (Mpa) }\end{array}$ & $\begin{array}{c}\text { Max. } \\
\text { Stress } \\
\text { (Mpa) }\end{array}$ & $\begin{array}{c}\text { Safety } \\
\text { Factor }\end{array}$ \\
\hline MPV & 400 & 52.23 & 7.65 \\
SUV & 400 & 58.84 & 6.79 \\
Sedan car & 400 & 43.93 & 9.10 \\
Commercial & 400 & 53.38 & 7,49 \\
Little truck & 400 & 53.28 & 7.50 \\
Big truck & 400 & 226.65 & 1.76 \\
Bus & 400 & 110.74 & 3.61 \\
MPV & 400 & 106.07 & 3.77 \\
SUV & 400 & 120.13 & 3.32 \\
Sedan car & 400 & 89.70 & 4.45 \\
Commercial & 400 & 111.99 & 3.57 \\
Little truck & 400 & 101.79 & 3.92 \\
Big truck & 400 & 397.02 & 1.007 \\
Bus & 400 & 230.83 & 1.73 \\
\hline
\end{tabular}

Tabel 5 indicates that the construction of the bow ramp door has a safety factor value between $1.007 \sim 9.10$. This figure shows that the bow ramp door construction is in the safe category because SF $>1$.

\section{Fatigue Life Of Bow Ramp Door Construction}

For high cycle fatigue analysis, it is assumed that the material has linear elastic behavior. Therefore, the fatigue damage is calculated considering the Palmgren-Miner rule in which the accumulated fatigue damage at a given stress level is equal to the number of stress cycles [14]. In addition, most fatigue failures are caused by cyclic loads. The final stage of this research is to determine the fatigue life of construction using Equation (12). Fatigue damage to determine is using Equation (7), (8), (9), (10) and (11). The values of fatigue damage, fatigue life for each of the maximum working stresses are shown in Table 6.
Tabel 6 shows that the fatigue life for each type of vehicle load using 2 load schemes is the shortest detected shown in the type of big truck with the type of load placement between the girders, equal 1.17 years. While the longest was detected in the type of sedan car with the type of load between on the girder, equal 398.64 years. From the stress and cycle data, S-N curves can be made for 2 types of loadcases. S-N curve loadcase type at girder is shown in Figure. 10.

Table 6.

The Fatigue Life of bow ramp door construction

\begin{tabular}{|c|c|c|c|}
\hline Vehicle type & Cycle & $\begin{array}{l}\text { Fatigue } \\
\text { Damage }\end{array}$ & $\begin{array}{c}\text { Fatigue Life } \\
\text { (years) }\end{array}$ \\
\hline $\mathrm{MPV}_{\mathrm{aG}}$ & $7.73 \times 10^{6}$ & 52.23 & 328.3 \\
\hline$S U V_{a G}$ & $5.34 \times 10^{6}$ & 58.84 & 218.86 \\
\hline Sedan caraG $_{a}$ & $9.05 \times 10^{6}$ & 43.93 & 398.64 \\
\hline Commercial $_{\mathrm{aG}}$ & $6.96 \times 10^{6}$ & 53.38 & 305.32 \\
\hline Little truckaG & $6.99 \times 10^{6}$ & 53.28 & 307.25 \\
\hline Big truck ${ }_{a G}$ & $3.77 \times 10^{5}$ & 226.65 & 9.31 \\
\hline BusaG & $7.33 \times 10^{5}$ & 110.74 & 23.6 \\
\hline$M P V_{b G}$ & $9.13 \times 10^{5}$ & 106.07 & 27.92 \\
\hline$S U V_{b G}$ & $6.86 \times 10^{5}$ & 120.13 & 18.27 \\
\hline Sedan carbG & $1.55 \times 10^{6}$ & 89.70 & 50.57 \\
\hline CommercialbG & $6.86 \times 10^{5}$ & 111.99 & 18.34 \\
\hline Little truckbG & $9.87 \times 10^{5}$ & 101.79 & 32.03 \\
\hline Big truckbG & $5.35 \times 10^{4}$ & 397.02 & 1.17 \\
\hline BuSbG & $3.6 \times 10^{5}$ & 230.83 & 2.29 \\
\hline
\end{tabular}

\section{S-N Curve loadcase type at Girder}

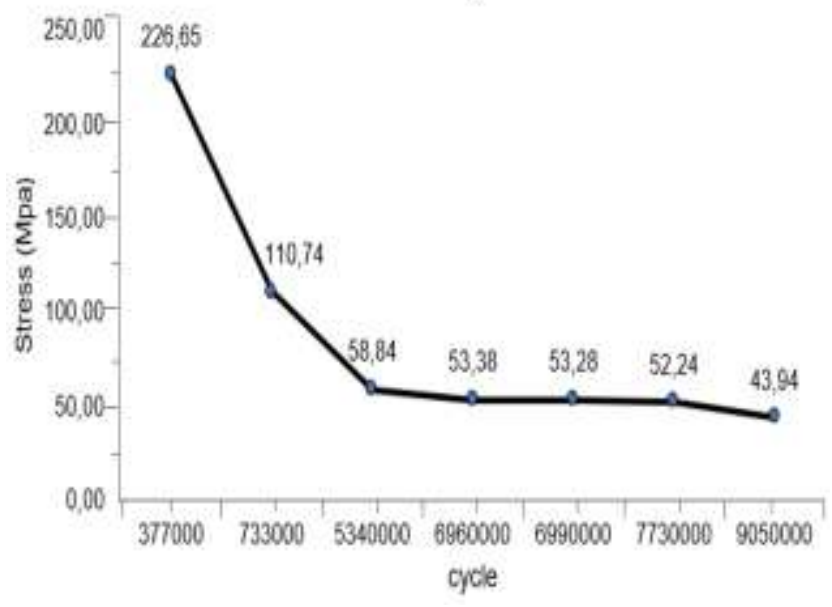

Figure 10.

S-N Curve of loadcase type at girder

Whereas the S-N curve loadcase type between girder is shown in Figure 11. 


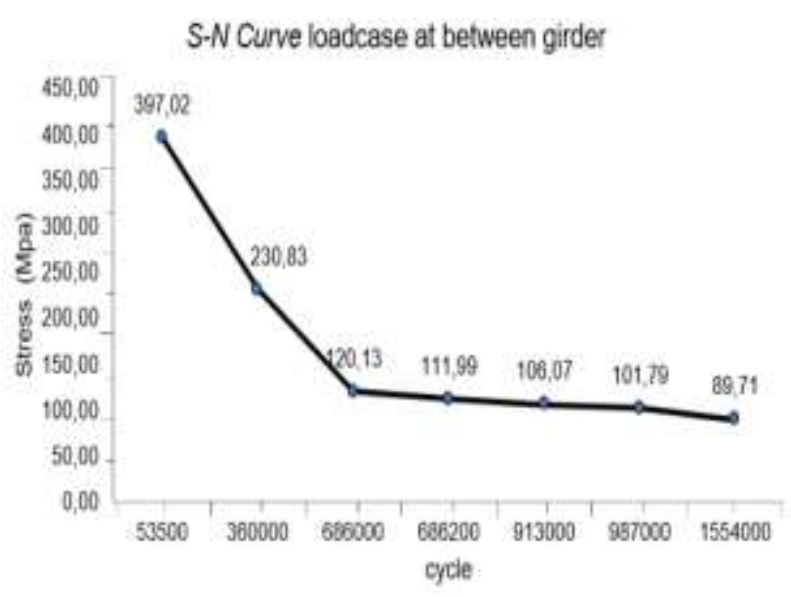

Figure 11.

S-N Curve of loadcase type at between girder

\section{CONCLUSION}

Bow ramp door construction is detected in safety condition with SF > 1 for all loadcase types and types of vehicles passing on it. The fatigue life value of bow ramp door construction has been modeled on finite element based applications. It was detected to have the minimum fatigue life value of 1.17 years which has a load cycle of $5.35 \times 10^{4}$ cycles. Meanwhile, the maximum fatigue life value was detected at 398.64 years which had load cycles of $9.05 \times 10^{6}$ cycles. In further research, it can be carried out with a variety of load cases and more varied types of vehicles in order to get more varied results.

\section{AUTHOR INFORMATION}

\section{Corresponding Authors}

Email: alamsyah@lecturer.itk.ac.id

Phone: +6285242800578

Email:09161015@student.itk.ac.id

Email: amaliaikaw@lecturer.itk.ac.id

Email: uswah.pawara@lecturer.itk.ac.id

\section{AUTHOR CONTRIBUTIONS}

Main contributor of this research is Alamsyah, the other authors is, Mapangandro A B, Amalia Ika Wulandari, and M U Pawara are supporting contributors.

\section{ACKNOWLEDGMENTS}

The authors would like to thanks the ship construction and engineering design laboratory of the shipping engineering study program for facilitating this research. Thanks also to the anonymous reviewer who has provided constructive input and suggestions so that this paper is worthy of publication.

\section{REFERENCES}

[1] U. Karlsson, Structural Safety Analysis of Bow-Doors. Göteborg, Sweden: Chalmers University Of Technology, 2004.

[2] BKI, Rules for the classification and Construction. Part 1 Seagoing Ship. Volume $\checkmark$ Rules for Materials. Jakarta: BKI, 2014.

[3] J. Johan, I.P.Mulyatno and G.Rindo, "Analisa Kekuatan Konstruksi Stern Ramp Door Sistem Steel Wire Rope Pada Kapal Penyebrangan Penumpang Ro-Ro 500 Gt Akibat Beban Statis Dengan Menggunakan Metode Elemen Hingga," J. Tek. Perkapalan, vol. 6, no. 1, 2018, pp. 111121.

[4] Alamsyah, A.I.Wulandari, and I.Fadillah, "The Strength Analysis of and Fatigue Life of Spob Propeller Shaft," Wave J. Ilm. Teknol. Marit., vol. 13, no. 2, 2019, pp. 91-98, doi: 10.29122/jurnalwave.v13i2.4162.

[5] Alamsyah, A.I.Wulandari, R.J.Ikhwani and J.A.Saka, "The Fatigue Life Analysis of TB Ship. $27 \mathrm{M}$ the Shaft Using the Finite Element Method," Inovtek Polbeng, vol. 10, no. 2, 2020, pp. 144-151, doi: 10.35314/ip.v10i2.1653.

[6] Alamsyah, W.Setiawan, N. S. Oktavaro, R. J. Ikhwani, A.I. Wulandari and M.E.H.A. Purba "An Analyze of Fatigue Life Construction of Lifting Poonton for Small Vessel," Proceedings of the $3^{\text {rd }}$ Bicame International Conference on Balikpapan, Indonesia, 2020, pp. 95-101 [Online]. Available: https://www.scientific.net/AST.104.95.pdf.

[7] R.Munandar, A. Ardianti, G. Sitepu, A.M. Nugraha, Hamzah and M.I. Hayatuddin "Study on Transverse Strength of the DeckContainer Ships Due to Laying All Containers on Deck," EPI Int. J. Eng., vol. 2, no. 2, pp. 178-184, 2019, doi: 10.25042/epiije.082019.14. 
[8] O.Fatra, E.Widoro and T.Y.P.Gultom "Analisis Struktur Velg Pada Modifikasi Airside Inspection Vehicle Menggunakan Perangkat Lunak Ansys," J. IIm. Aviasi Langit Biru, vol. 9, no. 3, 2016, pp. 13-22, [Online]. Available: http://stpicurug.ac.id/wpcontent/uploads/2018/02/Analisis-StrukturVelg-Pada-Modifikasi-Airside-InspectionVehicle-Menggunakan-perangkat-LunakANSYS.pdf.

[9] Anom, "Quarter ramps." MacGregor.com (accessed Apr. 04, 2021).

[10] DNVGL, Fatigue design of offshore steel structures. AS: DNVGL, 2019.

[11] Alamsyah, A.I.Wulandari and B.Harseno, "Analisa Kekuatan Bracket Pada Kapal RoRo Menggunakan Aplikasi Finite Element," SPECTA J. Technol., vol. 4, no. 3, 2020. pp. 97-105.
[12] Mapangandro A B, "Analysis of Fatigue Construction of Bow Ramp Door due to Dynamic Loads at KMP. Bahtera Nusantara with the Finite Element Method," Theses Kalimantan Institute of Technology, Unpublished, 2020.

[13] R. C. Hibbeler, Mechanics of Materials in SI Units, 10th Edition. Pearson, 2018.

[14] I. Lotsberg, "Development Of Fatigue Design Standards For Marine Structures," Proceedings of the ASME 2017 36th International Conference on Ocean, Offshore and Arctic Engineering on Trondheim, Norway, 2017, pp. 1-12. 